DOI: https://doi.org/10.15688/jvolsu4.2016.4.3

UDC 94(71)“1841/...”

Submitted: 17.07.2016

LBC 63.3(7Can)52

Accepted: 30.08 .2016

\title{
EGERTON RYERSON: \\ BUILDING A SPIRITUAL AND INTELLECTUAL FOUNDATION FOR A CANADIAN IDENTITY ${ }^{1}$
}

\author{
Robert M. Timko \\ Mansfield University, Mansfield, PA, USA \\ Aleksandr I. Kubyshkin \\ Saint Petersburg State University, Saint Petersburg, Russian Federation
}

\begin{abstract}
The article analyses the philosophical and political theories of Egerton Ryerson (1803-1882) - one of the leading figures of intellectual history of Canada in the 19th century. The authors concentrate their research on the religious, political and educational activity of Ryerson, on his vision of good government and reform of educational institutions in Upper Canada. Special features of the Scottish Enlightment are discribed as well.

Key words: Canadian methodism, Canadian philosophy, intellectual development in Upper Canada, Scottish Enlightment, educational reform in Canada, European trend in Canadian intellectual and political development.
\end{abstract}

УДК 94(71)“1841/...”

Дата поступления статьи: 17.07.2016

ББК 63.3(7Кан)52 Дата принятия статьи: 30.08 .2016

\section{ЭГЕРТОН РАЙЕРСОН: СОЗДАВАЯ ДУХОВНЫЕ И ИНТЕЛЛЕКТУАЛЬНЫЕ ОСНОВЫ КАНАДСКОЙ ИДЕНТИЧНОСТИ ${ }^{1}$}

\author{
Роберт М. Тимко \\ Мэнсфилдский университет, г. Мэнсфилд, Пенсильвания, США
}

Александр Иванович Кубышкин

Санкт-Петербургский государственный университет, г. Санкт-Петербург, Российская Федерация

Аннотация. В статье рассматриваются философские и политические взгляды Э. Райерсона (1803-1882) одного из ведущих представителей интеллектуальной истории Канады в XIX веке. Рассматривается влияние идей Шотландского Просвещения на формирование общественной и политической позиции Райерсона. Особое влияние уделено роли канадского методизма и его влиянию на политическую и общественную жизнь Верхней Канады. В статье анализируется характер дискуссий о необходимости проведения экономических и социальных реформ в Верхней Канаде и участие в этих реформах самого Райерсона. Затрагивается отношение Райерсона к формированию и развитию системы политических партий в Верхней Канаде, а также отмечается его глубокий интерес к изучению политической истории США, Англии и Шотландии. Анализируется 
практическая деятельность Райерсона в реформировании системы начального и среднего, а также высшего образования в Верхней Канаде, его вклад в становление и развитие канадской политической системы и гражданского общества в целом. Дается общая оценка роли Райерсона в формировании политической культуры канадского доминиона и значения его теоретического и практического наследия для современной Канады.

Ключевые слова: канадский методизм, канадская философия, интеллектуальная история Верхней Канады, Шотландское Просвещение, реформа образования в Канаде, европейское влияние на интеллектуальное и политическое развитие Канады.

Canada owes more to him than any other of her sons.

W. Ormiston

In part, what prompted us to write this reflection on the religious and secular philosophy of Egerton Ryerson was the discovery that though his leadership in public education is discussed in historical essays and textbooks, his foundational and profound influence on the development of Canadian political and social thought is not frequently affirmed in current literature. Even in the earliest years of his religious ministry, Ryerson began to solidify those values, ideals, and concepts which would form the foundation of his social, political, religious and educational philosophies. These philosophies in turn would help shape the identity of Upper Canada, and this is what we wish to demonstrate.

Adolphus Egerton Ryerson (1803-1882) was born into a prominent loyalist family in Charlotteville, Norfolk County, in what is now southwestern Ontario. His father, Joseph Ryerson, served on the British side in the American Revolutionary War and also participated, along with his three eldest sons, in the War of 1812. Egerton's youth prevented him from following in their footsteps and he concentrated instead on his studies - he was an avid reader of the classics and on a deeply religious training fostered by his father's Anglican conservatism and his mother's Methodist radicalism. Forced to choose between the two, he converted to Methodism (much to his father's chagrin) and left the family homestead at the age of 18 .

Historians and social scientists have differed on how much influence Methodism had on the shaping of Ryerson's philosophy. We think it is important to set aside the debate on whether there has been an overstatement of Ryerson's evangelical Christianity and for the sake of argument to assume that Ryerson's belief in a "Canadian Methodism", which was to be differentiated from both British and American forms of Methodism, helped form what he thought to be an appropriate social policy for Upper Canada. Perhaps this was in response to John Strachan referring to him as a liberal, an individualist and a traitor. The irony extends further in that the Americans saw him as too conservative and the British saw him as too individualistic and too republican. Finally, in a previous publication a claim was made that Canadian intellectual history ${ }^{2}$ begins in earnest with Ryerson's editorship of The Christian Guardian and most decidedly with his principalship of Victoria College. In light of that claim we will briefly explore how he may have synthesized ideas to be found in the Scottish Enlightenment with this Canadian Methodism to develop what he thought to be an appropriate plan of action for the moral, spiritual, intellectual and political future of Canada. The story of how that synthesis would occur begins with his sermons while riding the circuit, expresses its initial character in The Christian Guardian, exposes its intent in Ryerson's engagements with John Strachan, and matures in his vision for education in Canada. In terms of his educational vision one must of necessity examine Ryerson's principles for a liberal education together with the curriculum that he saw as derivative of those principles ${ }^{3}$. These principles and the curriculum can be found in Ryerson's "Inaugural Address on the Nature and Advantage of an English and Liberal Education" given in June 1842:

"The object of the system of instruction to the students who go through the whole College Course, is not to give a partial education, consisting of a few branches only; nor, on the other hand, to give a superficial education, containing a little of almost everything. $<\ldots>$ It is intended to maintain such a proportion between the different branches of literature and science, as to form a proper symmetry and balance of character. In laying the foundation of a thorough education, it is necessary that all the important faculties be brought into exercise. $<\ldots>$ The object of 
the Collegiate Course is not to teach what is peculiar to any one of the professions; but to lay the foundation which is common to them all. In the whole course of his literary and scientific education, the views, sentiments, and feelings of the student will be directed and cherished in reference to his intended profession or employment; but the general course of study contains those subjects only which ought to be understood by everyone who aims at a thorough education. The principles of science and literature are the common foundation of all high intellectual attainments - giving that furniture, discipline, and elevation to the mind, which are the best preparation for the study of a profession, or of the operations which are peculiar to the higher order of mercantile, manufacturing, mechanical, and agricultural pursuits.

And while it is designed in no respect to lower the standard of Classical and Mathematical Education, as maintained by the best scholars, the studies more immediately connected with the business of life, and the intercourse of society in this country" [13, p. 27].

There is some plausibilty to an assumption that the reference here to "English" in the title of the inaugural address refers to arguments and policies suggested by Durham in his report several years previously. Additionally, we think it can be safely argued that English Canadian educational institutions remained distinct from the pragmatic approaches of their American conterparts well into the latter half of the 20th century. American education and Dewey in particular would be criticized by a number of prominent Canadian philosophers, viz., Keirstead, Watson, Young, Lodge, Macdonald, etc. Canadian universities in particular seemed to resist the vocational and commercial trends of their American counterparts. The emphasis on a moral faculty or conscience of man seems to have persisted for decades more in Canadian education than in American education. Here one might see the influences of Hutcheson, Hume, Butler, Smith and others on the Canadian consciousness. The $21 \mathrm{st}$ century shows, however, Canadian education, including the universities, more closely aligning with their American counterparts. Further, we believe that Ryerson's vigorous pursuit of educational reform can in large part be attributed to an effort on his part to counter the charge brought by Strachan and others that not only were Methodist preachers disloyal, they were also uneducated, not properly trained, lacking in knowledge of true Christian principles, without discipline or sufficient moral character. In his Inaugural Address, Ryerson would go to great lengths to affirm the rigor of his ideal university curriculum. While affirming the importance of scientific, mathematical and professional education, he would also stress the importance of ethics, psychology and philosophy. Both "right knowledge" and "right principles" were needed in educational practice:

"Another most important and extensive department of a liberal education is Moral Science, embracing Mental Philosophy, Natural Theology, Moral Philosophy, and Logic. <...> The manner in which we are to exercise our minds in all our inquiries and duties is taught by Logic, which treats of the improvement and right use of our intellectual powers. To know our Maker and ourselves - to understand and discharge our duties towards both - to employ our intellectual and moral powers according to the principles of reason and truth, is the great end of our existence. It should, therefore, constitute a leading feature in every system of sound education. The youth should be furnished with right principles, as well as with right knowledge, for action. $<\ldots>$ The science of ourselves; the science of our duty; the science of our present and future well-being, ought not to be omitted, or made even a secondary object, in the science of education" [13, p. 17].

An awareness of a need for political, economic, and cultural independence for Canada existed at the time Ryerson initiated his educational policies ${ }^{4}$. Where Durham hoped that this would lead to embracing British values and culture, Ryerson would ensure that it eventually would lead to a development of a distinctly "Canadian" ethos. Ryerson, throughout his public career, remained insistent that a proper philosophy be a dominant feature of the Canadian curriculum. Politics, morality, economy, perceptions of the world and historical events would be shaped by a "Canadian" rather than by a British, French, or an American metaphysics, at least until the latter part of the twentieth century. Without drawing any conclusions about actual causal connections, imagine if you will what Ryerson may have imagined, given both his knowledge of the Durham Report and his knowledge of the Annexation Debates. Could part of his motive for restricting the import of U.S. texts and his insistence of the production of truly Canadian texts be better understood against the backdrop of a conservative 
political faith ${ }^{5}$ which advocated protectionism as a national policy?

What a study of the history of Canadian thought may reveal is a steady evolutionary development and preservation of the ideals articulated by Ryerson. What Ryerson brings to the early years of Canadian intellectual history is a synthesis of traditional religious values and moral authority with a critical idealism, thus initiating an emphasis on "reason" in Canadian thought which would remain in place through the mid-twentieth century. That Ryerson's vision is distinctively Canadian rather than merely reflections or modifications of British or American thoughts can be found in his defense of a "Canadian Methodism".

\section{The Nature of Canadian Methodism}

Ryerson went to great lengths to articulate how Canadian Methodism should be distinguishable from both British and American Methodism. He was sensitive to criticisms poured on him by both the Americans and the British (and by Strachan who saw Ryerson as promulgating American values).

In the decade which followed the War of 1812, the Americans continued to supply the majority of the Methodist circuit riders in Upper Canada. Though the Americans were consciously sensitive to the situation in Canada, the Canadians were still held accountable to and under the governance of the Genesee Conference, and in 1816 the General Conference in Baltimore upheld the position to maintain control over the church in Upper Canada. From the perspective of the loyalists in Upper Canada, this demonstrated nothing less than that the Canadian Methodists were under the control of a foreign government, and this had legal consequences. The Methodists were not able to hold lands on which to build chapels or bury their dead. Additionally, Methodist ministers were legally prohibited from solemnizing any marriages. The effect this had in Canada was an increasing and sometimes militant desire to gain independence from the American Methodist Episcopal Church. The Americans for their part believed that permitting such independence would be disastrous for church unity (and one must keep in mind that there existed a separate British Wesleyan tradition in Canada). Independence for the Canadian Methodists would come in 1828, but union with the British Wesleyans would not come for another five years ${ }^{6}$. "An independent Canadian Methodism has been no small factor in the creation of a united Canadian national spirit, as a part of the British Empire" [1, p. 82]. So what has all this to do with Egerton Ryerson?

"The new Canadian Methodist Church was now free to develop a thoroughly Canadian policy in founding church enterprises adapted to its distinctive Canadian needs. The first of these was a Methodist press. At the conference of 1829 steps were taken for the establishment of a weekly paper, to be called The Christian Guardian and Mr. Ryerson was elected editor and stationed at York. Henceforth this journal was to be the exponent of the views of Methodism on the great questions which agitated both the religious and the political sentiment of the country" [1, p. 82-83].

What we need to pay attention to is the conjunction of "religious and political sentiment" as exposited by Ryerson. At this time Ryerson was already notorious for his public responses to John Strachan on the issue of the Clergy Reserves and Strachan's defense of the Anglican Church as the established church of Canada with the authority to determine the curriculum for institutions of education ${ }^{7}$.

One should not underestimate the influence of the Methodist faith on Ryerson's character and his motives for acting in the political and educational arenas. Even Colin Pearce who suggests there may have been an overemphasis of how much religion (Methodism) in particular help shape Ryerson's educational and political policies makes the following observation:

"Ryerson's claim is that political economy and philosophy are necessarily incomplete to the extent that they do not confront the moral-religious dimension of human existence. It follows from this very claim that Ryerson himself sought to make such a confrontation. This means that his views on religion must be considered before the full shape of his political thought can come to light" $[5, \text { p. } 787]^{8}$.

Ryerson clearly saw "Canadian Methodism" as founded in a principle of benevolence, which he defines as a voluntary suffering for the sake of other [8, p. 260]. Characteristic of this benevolence is a moral sympathy which identifies with the labours and needs of ordinary people be 
they European settlers or native Canadians. It is about sacrificing self-interest for the good of a people. In the second chapter of his work on Canadian Methodism, Ryerson details the character and work of several Methodist missionaries (Case, Coleman, Losee, and Bangs) in order to prove this point. Ryerson demonstrated this benevolence and moral sympathy in his own character and labours. We draw your attention to his diary entries of 1826-1827 of his work among the Credit River Indians which can be found in his autobiography. Chapter V included in this diary is a letter reporting his labours written by his brother George (March 8, 1827):

"I visited Egerton's Mission at the Credit last week, and was highly delighted to see the improvement they are making both in religious knowledge and industry. I preached to them while there, and had a large meeting and an interesting time. The next morning we visited their schools. They have about forty pupils on the list, but there were only thirty present. The rest were absent, making sugar. I am very certain I never saw the same order and attention to study in any school before. Their progress in spelling, reading, and writing is astonishing, but especially in writing, which certainly exceeds anything I ever saw. They are getting quite forward with their work. When I was there they were fencing the lots in the village in a very neat, substantial manner. On my arrival at the Mission I found Egerton, about half a mile from the village, stripped to the shirt and pantaloons, clearing land with between twelve and twenty of the little Indian boys, who were all engaged in chopping and picking up the brush. It was an interesting sight. Indeed he told me that he spent an hour or more every morning and evening in this way, for the benefit of his own health, and the improvement of the Indian children. He is almost worshipped by his people, and I believe, under God, will be a great blessing to them" $[15$, p. 69].

We can observe here some evidence that Ryerson believed in a strong connection between religion, education, the virtue of industry, and the community welfare.

\section{The Scottish Enlightenment and Canadian Thought}

Scottish Common Sense philosophy would have an appeal in both the American colonies and Upper Canada. This philosophy as articulated by Thomas Reid would persist in the U.S. and eventually merge into American pragmatism. The early appeal in Canada would be for its rejection of Hume's skepticism and its claim that an understanding of the world could be available to all. Canada, however, would be attracted to more idealistic approaches to knowledge and moral action. In the latter regard Canadians would favour an ethic founded on benevolence, compassion, and conscience. In this regard the moral philosophies of Francis Hutcheson, Adam Smith, and David Hume would find a home in Canada. For example, Smith argued for the value of productiveness and the pursuit of individual interest because both were beneficial to the community. Smith argued for benevolence and sympathy as a basis for morality. Both placed limits or restraints on self-interest ${ }^{9}$.

Ryerson was a contemporary of William Hamilton and would have been acquainted with what individuals such as Hutcheson, Smith, Hume, James Mill and J. R. McCulloch had written. Ryerson would publish what he would call his three "gratuitous contributions to an important branch of useful knowledge", viz., First Lessons on Agriculture (1870), First Lessons in Christian Morals (1870), and Elements of Political Economy (1877) [10;11; 12]. In the "Prefatory Notice" to the last mentioned work, for example, Ryerson claimed though the "definitions, explanations and illustrations" were his own, the material contents were derivative of the work of Adam Smith and J. R. McCulloch, among others. The subtitle of the First Lessons in Christian Morals was "For Canadian Families and Schools". In the "Prefatory Notice" to this volume he claims an assumption of the "truth of Christianity" and the "authority of the Bible". The material contents or "lessons" of this work emphasize duties, conscience as a moral faculty, the moral quality of actions, and a brief discussion of his objections to certain aspects of Hume's philosophy (the nature of religion and what Hume says about miracles). An emphasis on duties or social obligations is characteristic of Canadian moral and social philosophy in contrast to the emphasis on individual rights and liberties that can be found in both American and British moral and legal thought. Consider what Ryerson has to say about the relation between happiness and benevolence in First lessons in Christian Morals:

"Man is born for society; and the play of the social affections, in being surrounded by the objects 
of endearment, as in the domestic circle, or with companions, produces cheerfulness and enjoyment; while peevishness and lowness of spirits attend the recluse and solitary. The exercise of the benevolent, no less than of domestic and social affections, refreshes the spirits and produces grateful and pleasurable emotions, in acts of sympathy, kindly counsel, and bounty to the afflicted, the unfortunate and the needy" [11, p. 91].

What is said here by Ryerson is compatible with Hume's reflections on the social nature of man, sympathy, benevolence, and interest in the welfare of others. Hume was most decidedly influenced by Hutcheson ${ }^{10}$ who argued that humans are instinctively benevolent. We believe what Ryerson says here also goes against a claim made by Colin Pearce in his essay on Ryerson's Canadian liberalism, viz.,

"Following thinkers like Hume and Smith he argued that "active sympathy" in social relations "is the arterial life of a country's social advancement". But caution is necessary here. Ryerson was not for these reasons anything remotely resembling a devotee of what today we might loosely call "communitarianism". He defined society as a "union of individuals $<\ldots>$ prompted by the original impulses of man and imposed by his necessities". Thus there is an ambiguity in Ryerson's analysis of individual and society" [5, p. 776-777].

Ryerson, contrary to Pearce's claim, articulated a belief which can be shown to be consistent with claims made by other Canadian philosophers who can be claimed as communitarian in their political and social outlook. For example, examine if you will the philosophical idealism of Jacob Gould Schurman (1854-1942) who became a distinguished American educator and diplomat ${ }^{11}$, but who remained at heart distinctively Canadian ${ }^{12}$.

For Schurman moral theory as discovered by reason needs to be enlightened by an experiential knowledge (the appearance of a pragmatic outlook or so it may seem) or a "specific knowledge of moral practice". Such knowledge may be experienced differently in a society which is communitarian in nature than in a society in which the rights and/or interests of an individual can take precedence over a community or common good. Schurman argues that "the moral law is properly regarded as simple and unanalyzable or ultimate. When it is said that justice is right, that benevolence is a duty, that stealing or lying is wrong, we must not attempt to demonstrate these propositions by means of others, but directly and immediately assent to them as carrying their own weight" [17, p. 217], and further that "morality [is] the indispensable condition of social existence, it is coextensive with humanity" [17, p. 218]. Justice, benevolence and similar principles have no value (though they may have meaning) in a purely formal or theoretical context. We need to know the "experiences" of the community in which they occur. (We ask you recall that Ryerson argued for a Canadian Methodism founded on benevolence.) "The territory of a community", Schurman tells us, "is at once the scene and the indispensable condition of the national life, and a determining factor in its development" [18, p. 2]. For Canada, this means it must look at its past in relation to its present to determine which political and moral forces are at work and if they are the appropriate forces. For Canada's future can be settled only by its own character. Schurman is very clear on this point: "[C]ommunities grow to the burden they bear. And Canada is no exception to the rule $<\ldots>$ there must be no break with the past" $[18, \text { p. } 17]^{13}$. We argue that Ryerson own beliefs can be held to be consistent and compatible with this articulation of benevolence and justice in Schurman's thought.

Part of the problem may be that Pearce confuses what he labels as liberalism with a moral conservatism that was characteristic of both North American and British moral philosophy in the nineteenth century. This "moral conservatism" must be understood within a nineteenth century context, where "conservatism" meant not only a respect for a unified moral order, but also implied a pursuit of a commonly perceived social good. Metaphysically, this conservatism was decidedly idealistic, and politically, it was socialistic. The "community good" was understood to be the primary value, and any emphasis on individual interest or on the possession of competitive rights was seen to be in opposition to this "good". Concern for others and the performance of social duties were to be emphasized in the educational process. This concern for others, this sympathy for man can be found both in Ryerson's letters, diaries and sermons as well as in the way he lived his life. For Ryerson there had to be a necessary conjunction of religion, politics and education if 
there were to be any hope of happiness for the community. To be fair, Pearce does recognize this aspect of Ryerson's thought:

"Given the various social and political forces that modern civilization had unleashed, Ryerson was inclined to the view that "the common Biblical inheritance of Christendom" was more crucial to the moral health of civil society than at any time previously. If the knowledge of Biblical religion were to atrophy "there would be comparatively no instruction in duties and virtue" and this would have grave consequences for "the happiness of society"" [5, p. 789].

And when characterizing Ryerson's approach to the study of political economy, Pearce notes:

"In line with his reading of Burke Ryerson sought to reconcile the practical necessities of modern economic and political life with a concern for longstanding "feelings, associations and sympathies". These things, which are the product of the people's shared historical experience form part of the public mind and must form part of political leaders' calculations when they are deliberating policy. In the specifically Canadian context Ryerson was a Burkestyle defender of such "irrational" traditional institutions as the monarchy which, with its symbolism and history, could elevate the citizens' gaze, at least momentarily, beyond the taste for physical gratification and the single-minded pursuit of wealth. Such institutions, while in no way compromising the progressive, commercial and egalitarian principles of the wider society, serve to temper and moderate those pernicious tendencies to which these very principles give rise" [5, p. 785-786].

We contend that if anything Ryerson adhered to a form classical conservatism which can be found in both Edmund Burke and Adam Smith. Contrary to Pearce, we cannot find support for a claim that Ryerson can be seen as a liberal if by that term we mean someone in the tradition of a John Locke or J.S. Mill. Pearce claims that it is Ryerson's beliefs in "private property, a free economy, freedom of speech, religious tolerance, church-state separation and representative government" [5, p. 795] that place him in the liberal tradition. What is absent in Ryerson is any defence of atomic individualism or philosophical materialism both of which are hallmarks of the liberal tradition. If one examines closely what Ryerson was saying about moral conscience and responsibility, the good of the community and why he was arguing for religious tolerance, he can be seen to be firmly positioned within a classically "conservative" tradition. For example, let us briefly look at the issue of church-state separation and religious tolerance. Ryerson's defense of these things was not so much political as it was moral and spiritual. Previously we mentioned that Ryerson saw Canadian Methodism as anchored in the principle of benevolence. From a spiritual perspective he saw Canadian Methodism as characterized by the doctrine of "the Triune Godhead, the atonement of Jesus Christ, and the resultant work of the Holy Ghost" [8, p. 72]. Ryerson would criticize other Christian denominations for their repeated failures to preach these doctrines even though these doctrines were fundamental to various and many denominational creeds. This belief in their moral and spiritual laxity would be foundational to his opposition to an established church. Ryerson would argue that is an established church which leads to pride and intolerance and perhaps to "animosity" [8, p. 210]. For Ryerson it was simple, religion should not rest on human law nor should a natural interdenominational harmony and charity be disturbed, all of which would occur if there were an established church. Such a church was not necessary for either the "security of the government" or the "loyalty of a people". Nor was it sufficient since establishment was not a natural goal or end of religion. Ryerson preached religious tolerance and church-state separation not from a legal or political standpoint, but rather from the standpoint of a conservative religious, moral, and metaphysical perspective. Even from a political perspective it might be argued an established church would be problematic if one were to consider good politics as grounded in reason and morality. As Ryerson would argue "[I]f the church is incorporated with the State, they [the citizens of the state] may be compelled by the obligations of conscience to oppose one of the civil institutions of a country $<\ldots>$ In fact it is a duty to do so" [8, p. 209].

Can Ryerson be counted as squarely within the tradition of Canadian liberalism? We think it safe to say that though he was sympathetic to political and religious reformers, he would consistently oppose individual reformers, or their actions, if they violated what he held as moral 
principle. In Egerton Ryerson and Education in Upper Canada, J. Harold Putnam notes that "Ryerson never had been, and never became, a mere party man. He fought for great principles, and if up to 1844 he had generally found himself with the Reformers, it was because they were championing what Ryerson believed to be right" $[7$, p. 24$]{ }^{14}$. By bringing together the endeavours and goals of the Christian religion, public education and politics, Ryerson quite possibly laid the foundations for social policy in Canada, such policies remaining in place until the latter half of the $20^{\text {th }}$ century.

\section{Ryerson on the Nature of Good Government and Political Parties}

\section{Partyism}

There is perhaps one area in which Ryerson's did not exert full influence on Canadian society and that was in regard to his musings on the nature of political parties and the needed for a government if it were re to be responsible to the needs of a people be grounded in moral and religious principle rather than in the competitive interest of rival political parties. Ryerson's attitude toward political parties can be found in some of his responses to the issue of the clergy reserves, but can certainly be seen in his "Impressions" essay. His characterizations of English political parties shows how he would see that "partyism" as a practice would evolve and exist in contradiction to responsible government. We can also see here the beginnings of his lifelong opposition to "radical republicanism" since he would consistently associate such radical republicanism with an opposition to true and principled reform. Burwash notes that Ryerson saw "danger both to the British monarchical government and to religion and morality in the principles of the English radicals, [and Ryerson] began to be suspicious of their Canadian friends" [1, p. 109]. According to Burwash, Ryerson genuinely feared the establishment of a republic in Canada. Also keep in mind that Ryerson believed that education should have as it goal the building of character or civic virtue. Sound government should be founded on moral principles which in turn were grounded in religious faith. There should always be an intimate connection between religion, politics and education.
If Ryerson can be credited with building the educational system of Upper Canada and fostering religious tolerance and to some extent political reform, he perhaps did not succeed as well as should have in helping shape a non-partisan government. Note well that Ryerson was not opposed to parties or associations which acted on moral principle in a just cause:

"I know it will be alleged, that I object to all parties or associations for legislative or governmental purposes. I do nothing of the kind. Parties have been formed and associations have been organised and sustained to abolish the slave trade and slavery, to promote parliamentary reform, to abolish the corn laws and establish free trade, and, in this country, to obtain equal rights and privileges for all classes, and to abolish an irresponsible system, and secure a responsible system of government" [14, p. 15].

Ryerson saw parties founded in moral principle as instruments of promoting the good of the community. What he opposed was partisanship and government according to the self-centered party interest rather an educated moral sensibility. "Partyism" as he called it was an ideology in opposition to, if not destructive of, the public good. $\mathrm{He}$ envisioned a system in which government ministers would be appointed because of their wisdom and character rather than their party affiliation. Responsible government requires both moral character and clear qualification for the office rather than adherence to a "politicism" [14, p. $17 \mathrm{ff}]$. Ryerson was not one to mince his words: "this party faction system of government tends to eat out the life of religious feeling, subverts the principle of public morality, and undermines the essential elements of social progress" [14, p. 17]. He would go on to associate "partyism" with a lack of charity, slanderous behaviour, and the lowering of moral standards. "Truthlessness and dishonesty in politics - the essence of partyism - is the certain forerunner of truthlessness and dishonesty in all social relations" [14, p. 18]. Partyism worked in opposition to real reform which Ryerson saw as "equal rights and privileges among all classes without regard to sect or party" [14, p. 19].

For Ryerson it was simple - the greatness of a country could be measured only in terms of the moral character and intellect of its public servants and its citizens. Partyism drives people of character away from public service: 
"Partyism, with its proscriptions and calumnies, has deterred and driven from political life the best and ablest men in the United States, and has caused a melancholy decline in the character of their public men. $<\ldots>$ and in many instances extinguished individual freedom of thought, and individual independence in public affairs, has convulsed and corrupted society, and caused unprecedented civil war and bloodshed" [14, p. 26].

He goes on to argue that individuals bound by party policy do not look out for the good or interest of a country; they are preoccupied with maintaining the approval of the party and its consequent rewards. Responsible government requires knowledge and character, and, most importantly, a dedication to applying governmental practice to the needs of the people rather than to the advancement of party interest or ideology. Partyism he saw as "debauching and debasing" to those who were interested in the public life. His ultimate advice to the people of Canada was that it is "the duty of friend to the success and prosperity of the Dominion of Canada to discountenance by every lawful means such partyism, from whatever quarter it may proceed, or by whatever parties it may be practised" [14, p. 28]. One can only imagine what government would like had Canada adhered to the moderate conservative approach to politics advised by Ryerson ${ }^{15}$.

\section{Education, Citizenship, and Good Government}

Hopefully, we have demonstrated that Ryerson certainly believed "partyism" to be an obstacle to the establishment and maintenance of "good government". Such a government required individuals of high moral character, whose primary interest was the good of the commonwealth. Such character, in turn, would be forged through the educational process. For Ryerson a proper education was not only a necessary condition for the reasonable and moral exercise of liberty, it was also essential to the exercise and maintenance of both responsible citizenship and good government. On several occasions, Ryerson reminds us that good government should act as a moral restraint on the undisciplined exercise of liberty ${ }^{16}$. Liberty, in turn should never be confused with the absence of governmental restraint. In his Discourse on Civil Government, Ryerson observes that "some mistake liberty for an exemption from government, and think they are most free, when they are most ungoverned, and may do what they list..." [9, p. 14]. The function of liberty, he argues, is simply to do good. Doing good requires wisdom, and wisdom comes with a proper education. Goodness in government is to be found in the very character of the governors and citizens, and so it follows that neither governors nor citizens ought not to act in a self-interested or vengeful manner. For Ryerson, "the public good is of greater value than the righting of a personal insult or injury" [9, p. 12]. Further, "[w]hen everyone is shifting for himself, and saving his own, and murmuring at the charge by which their safety must be defended, - this selfishness is the most pernicious enemy to the government and the common good" [9, p. 14].

Perhaps it would be helpful to recall that Ryerson leaned heavily on his Christian convictions and believed that humans were naturally sinful, or in more secular terms fallible, overwrought with passion, and selfish in nature. At times he appears quite Hobbesian in his assessment of human nature and its need for government.

"The legitimate end of civil government is the preservation and advancement of men's civil interests, and the better security of their lives, liberties, and property. Without civil government of some kind, there would be no security against mutual invasions and injuries; every man might act as his interest or his passions at the moment led him, and no man's property or life would be secure for half an hour; the possessions, liberties and lives of the weak would be at the disposal of the strong; disorder, confusion, mischiefs, murders, and ten thousand miseries would overspread the earth, and the human race would soon become extinct. So obvious is the necessity of civil government, that we read of no age in which it did not exist. I believe it is coeval with the human race" [9, p. 3-4].

This assessment of human nature which appears quite early in the Discourse coincides with sentiments Ryerson expressed in several of his works. If we join these beliefs with what he says in the opening of his Inaugural address, viz., "Man is made for physical, mental, and moral action; and the grand object of education is to develope, improve, and perfect, as far as possible, his physical, mental, and moral faculties" [13, p. 9], we have the metaphysical and epistemological 
bases for his political philosophy. (We draw your attention to the second citation from his Inaugural Address which appeared earlier in this paper.) The purpose of education is to help individuals live well as good citizens and govern well as leaders in the commonwealth. Education should emphasize the duties and responsibilities of both the rulers and the ruled. Character development is of equal, if not greater, value than the study of the sciences, literature, mathematics, languages, rhetoric, and logic.

We believe that the evidence would support a claim that Egerton Ryerson dedicated his life and work to advancing and securing the spiritual, intellectual, moral, and political wellbeing of Canada and its individual citizens ${ }^{17}$. His faith provided the spark for his opposition to the establishment of a state religion which would have the sole authority to determine how a nation's citizens would learn and what they would learn. His faith helped him frame a plan of action for the education of all without regard to religious, economic, or political interest. There should be universal access to a sound education that would develop and promote individual, and consequently, community well-being. His path was neither pragmatic nor utilitarian; it was objectively idealistic. Education, for Ryerson, was not a privilege of the wealthy, nor should its interests be forged by either a narrow religious or political sectarianism ${ }^{18}$. The political well-being of Canada demanded a people be morally committed to the interests and wellbeing of all, of the community as a whole. This goes beyond both majority interest and the greatest good of utilitarianism. An educated citizenry would more likely ensure that performance of our duties to ourselves and others would be highly valued and would restrain an unreasoned and selfish exercise of rights. This brings us to the final question, viz., who was Egerton Ryerson? He was a devout Christian, a philosophical idealist, an activist constantly promoting social transformation, a defender of the right of all to the best education, a servant of the people of Upper Canada, a leader in his church and his community, an opponent of tyranny in any of its many guises, Canada's first and foremost public intellectual. A man to whom Canada owes much, including its identity as a nation and a people.

\section{NOTES}

${ }^{1}$ An earlier version of this paper was presented by Professor Timko at the MANECCS 2014 Conference in Niagara Falls, Ontario, September 26, 2014.

${ }^{2}$ Canadian intellectual history or philosophy is characterized by an objective idealism and an ethical/political communitarianism in opposition to the pragmatic and utilitarian views found in American and British thought. Canadian thought also deliberately separates itself from the rugged and atomistic individualism characteristic of American thought [21].

${ }^{3}$ In this regard, one may wish to refer to the study of education in Upper Canada by Alison Prentice. Prentice points out that both Strachan and Ryerson saw a lack of civilized culture in the U.S. Ryerson believed that the events of 1837 were in part caused by the influence of American schoolbooks. He claimed the U.S. psyche as filled with racial prejudice and wanted rid Canada of the "republican, chauvinist, antiBritish literature from the U.S." [6, p. 53].

${ }^{4}$ It should also be noted that Lord Durham had called for a more comprehensive system of primary education in Canada. Ryerson was in agreement with this sentiment.

${ }^{5}$ A phrase used by W.C. Keirstead, an educational and social reformer in early $20^{\text {th }}$ century New Brunswick.

6 That union would be dissolved in 1840 and re-established in 1847.

${ }^{7}$ Most problematic for Ryerson would be as he saw it an attempt to control the education of the clergy.

${ }^{8}$ Pearce also claims that "[f]or a society to hope for enduring freedom and progress, it must go beyond the sciences of economics and government and focus on the moral, which is ultimately to say the religious, dimension of human existence" [5, p. 787].

9 Additionally, it should be observed that although Objective Idealism had a brief but interesting life in the U.S., it became part of the architecture of Canadian thought and culture. In terms of ethical behaviour, utilitarianism with its calculation of benefits and costs would take hold in the U.S., finding a compatibility with American pragmatism, but the doctrine of utility would be consistently rejected in Canada (one might refer to the ethical writings of Young, Murray, and even Ryerson as examples). Canadian moral philosophy would evolve as very much less calculative and more compassionate in its approach. Also, one finds the undertones of what Hume would call social approbation and disapprobation in Canadian thought.

${ }^{10}$ Despite the fact that Hutcheson would oppose Hume being appointed to the Chair of Moral Philosophy at Edinburgh. 
11 President of Cornell University, President of the Philippine Commission, U.S. Ambassador to Greece and Macedonia, China, and Germany.

12 Our use of Schurman is not arbitrary. Not only would Schurman's ideas about benevolence and community be consistent with those held by Ryerson, Schurman would also warn educators of the dangers of political partisans using public education to empower their political biases. For example see his Presidential Address to the $14^{\text {th }}$ Annual Meeting of the National Association of State Universities, October 1909 [16, p. $7 \mathrm{ff}]$.

${ }_{13}$ Professor Timko previously made this argument in several addresses and papers, most notably in Timko, Robert M. "Telling the Story: 'History' and the development of Social Theory and Practice in Canada", from which we quote directly [21, p. 19-20].

${ }^{14}$ Early in the same work Putnam recounts the controversy surrounding particular publication by Ryerson: "In 1833, Ryerson published in the Guardian 'Impressions Made by My late Visit to England'. In this article, he gave his estimate of Tories, Whigs, and Radicals. He saw much to admire in the moderate Tories, little to praise in the Whigs, and much to condemn in the Radicals. < .. > Ryerson's articles led constitutional reformers in Upper Canada to separate themselves from those reformers who were prepared to establish a republican form of government in order to secure equal political and civil rights" [7, p. 14]. Wm. Lyon McKenzie called Ryerson's views heretical.

${ }^{15}$ Things began to unravel after 1982 with the more "liberal" approach of the Charter and conservatism in its traditional sense began to fragment. With Harper's ascension to the "New Conservative" leadership, what we actually encounter is a move toward classic liberal individualism, pragmatic in nature, and in natural opposition to the concepts of a community and an overarching good. Idealism is lost as rights replace duties as the essential characteristic of the Canadian polity.

${ }^{16}$ Historically, it can be observed that in the predominantly libertarian United States, individual liberty continually poses as a trump card in legislative, judicial, and political debates; whereas, in a more communitarian Canada, the good of the commonwealth has been more highly valued in such debates. It should be acknowledged that even the liberal 1982 Charter recognizes that right and liberties can be exercised only within "reasonable limits".

${ }^{17}$ For a good example of such evidence, we direct our readers to Ryerson's remarks on pages 7 and 8 of his "Address on the New Dominion".

${ }^{18}$ Ryerson refers to the pursuit of sectarian interests in schools as a form of partyism which is injurious to welfare of the community.

\section{REFERENCES}

1. Burwash N. Egerton Ryerson. Toronto, Morang and Co. Ltd, 1903. 303 p.

2. Hutcheson F. Essay on the Nature and Conduct of the Passions and Affections: With Illustrations in Moral Sense. London, F. Darby and T. Browne, 1728. 333 p.

3. McCulloch J.R. The Principles of Political Economy: With a Sketch of the Rise and Fall of the Science. Edinburgh, William Tail, 1843. 574 p.

4. McKillop A.B. A Disciplined Intelligence: Critical Inquiry and Canadian Thought in the Victorian Era. Montreal, McGill-Queens University Press, 1979. $287 \mathrm{p}$.

5. Pearce C.B. Egerton Ryerson's Canadian Liberalism. Canadian Journal of Political Science = Revue canadienne de science politique, 1988, vol. 21, no. 4 (December), pp. 771-793.

6. Prentice A. The School Promoters: Education and Social Class in Mid-Nineteenth Century Upper Canada. Toronto, McClelland and Stewart, 1977. 192 p.

7. Putnam J.H. Egerton Ryerson and Education in Upper Canada. Toronto, William Briggs, 1912.270 p.

8. Ryerson E. Canadian Methodism; Its Epochs and Characteristics. Toronto, William Briggs, 1882. $440 \mathrm{p}$.

9. Ryerson E. Civil Government - the Late Conspiracy. A Discourse Delivered in Kingston, U.C., December 31, 1837. Toronto, 1838. 20 p.

10. Ryerson E. Elements of Political Economy or How Individuals and a Country Become Rich. Toronto, Copp, Clark and Co., 1877. 168 p.

11. Ryerson E. First Lessons in Christian Morals for Canadian Families and Schools. Toronto, Copp, Clark and Co., 1871. 94 p.

12. Ryerson E. First Lessons on Agriculture for Canadian Farmers and Their Families. Toronto, Copp, Clark and Co., 1870. 225 p.

13. Ryerson E. Inaugural Address on the Nature and Advantages of an English and Liberal Education. Toronto, By order of the Board of Trustees and Visitors, Guardian Office, 1842.34 p.

14. Ryerson E. The New Canadian Dominion: Dangers and Duties of the People in Regard to Their Government. Toronto, Lovell and Gibson, 1867. 35 p.

15. Ryerson E., Hodgins J.G., ed. The Story of My Life (Being Reminiscences of Sixty Years Public Service in Canada). Toronto, William Briggs, 1883.612 p.

16. Schurman J.G. Address Delivered at the Fourteenth Annual Meeting of the National Association of State Universities Held in Boston, October $8^{\text {th }}-9^{\text {th }}, 1909$. Boston, 1909. $39 \mathrm{p}$.

17. Schurman J.G. The Ethical Import of Darwinism. New York, Charles Scribner's Sons, 1887. 264 p. 
18. Schurman J.G. The Manifest Destiny of Canada. New York, Forum Publishing Co., 1889. 17 p.

19. Sissons C. Canadian Political Ideas in the Sixties and Seventies: Egerton Ryerson. Report of the Annual Meeting of the Canadian Historical Association = Rapports annuels de la Sociütü du Canada, 1942, vol. 21, no. 1, pp. 94-103.
20. Smith A. The Theory of Moral Sentiments. London, Millar, Kincaid and Bell, 1767. 538 p.

21. Timko R.M. Telling the Story: "History" and the Development of Social Theory and Practice in Canada. Representations of Canada: Cross-Cultural Reflections on Canadian Society. Volgograd, Izd-vo VolGU, 2008, iss. 5, pp. 13-49.

\section{Information About the Authors}

Robert M. Timko, PhD, Professor Emeritus, Mansfield University, Swan St., 5, 16933 Mansfield, PA, USA, robertimko@comcast.net.

Aleksandr I. Kubyshkin, Doctor of Sciences (History), Professor, Saint Petersburg State University, Smolnogo St., 3/1, 119161 Saint Petersburg, Russian Federation, kubyshkin.alexander@gmail.com.

\section{Информация об авторах}

Роберт М. Тимко, $\mathrm{PhD}$, почетный профессор, Мэнсфилдский университет, ул. Свон, 5, 16933 г. Мэнсфилд, Пенсильвания, США, robertimko@comcast.net.

Александр Иванович Кубышкин, доктор исторических наук, профессор, Санкт-Петербургский государственный университет, ул. Смольного, 3/1, 119161 г. Санкт-Петербург, Российская Федерация, kubyshkin.alexander@gmail.com. 